\title{
Wpływ przygotowania powierzchni na lutowność stali austenitycznych
}

\section{Influence of surface preparation on the solderability of austenitic steels}

\section{Streszczenie}

W artykule przedstawiono techniki oczyszczania powierzchni z tlenków oraz zanieczyszczeń (smarów, olejów, zadziorów, opiłków i innych) powierzchni obrabianego metalu. Przedstawiono również trudności występujące przy lutowaniu stali austenitycznej.

\section{Wstęp}

Ciągły rozwój techniki wpływa na zwiększenie wymagań stawianych materiałom co do właściwości mechanicznych i odporności na korozję. Bardzo ważnym problemem dla przemysłu jest dobranie odpowiednich materiałów do pracy $w$ określonych warunkach [1]. Stal nierdzewna to ogólny termin obejmujący dużą grupę materiałów w mniejszym lub większym stopniu odpornych na korozję. Jest to zależne od składu chemicznego stali oraz od rodzaju obróbki cieplnej, jakiej była poddana. $Z$ tego powodu stale nierdzewne podzielono na grupy. $W$ tym artykule przyjęto temat stali austenitycznych.

\section{Stal austenityczna}

Stal austenityczna charakteryzuje się wysoką odpornością korozyjną i temperaturową oraz wytrzymałością mechaniczną w zakresie od 450 do $950 \mathrm{MPa}$.

Mgr inż. Sylwia Mosińska, prof. dr hab. inż. Andrzej Ambroziak, dr inż. Artur Lange, dr inż. Piotr Białucki - Politechnika Wrocławska.

\section{Abstract}

The paper presents techniques for cleaning the surface to elimination of oxides and contaminants (grease, oil, burrs, chips and other) from the surface of the machined metal piece. It also presents difficulties of soldering austenitic steel.
Stale te są odporne głównie na korozję chemiczną, $\mathrm{w}$ tym na utlenianie $\mathrm{w}$ atmosferze powietrza, pary wodnej, na działanie zimnych roztworów alkalicznych, rozcieńczonych kwasów i soli z wyjątkiem chlorków, siarczanów i jodków oraz na działanie ropy naftowej i jej par, paliw, olejów, alkoholi, a także środków spożywczych. Duża odporność na korozję spowodowana jest zawartością w stali co najmniej $11 \%$ chromu [2]. Przy takiej zawartości następuje gwałtowna zmiana potencjału elektrochemicznego na dodatni. Na powierzchni stali tworzy się niewidoczna gołym okiem błona tlenków zapobiegająca korozji. Drugą istotną cechą stali nierdzewnej (obok dużej odporności korozyjnej) jest zdolność do natychmiastowej regeneracji powierzchniowej błony ochronnej w miejscach uszkodzenia, np. zarysowania. Ta wyjątkowa cecha nosi nazwę samopasywacji i jest wynikiem obecności kilkuatomowej grubości warstwy tlenków pierwiastków stopowych. Właśnie ze względu na te właściwości zastosowanie stali austenitycznej jest bardzo szerokie, począwszy od środowiska wodnego o bardzo dużej agresywności, przez przemysł chemiczny i petrochemiczny, konstrukcje lotnicze, okrętowe, kolejowe, budowlane, po sprzęt gospodarstwa domowego, między innymi przy produkcji zmywarek, pralek, zlewozmywaków, garnków, lamp i wielu innych (rys. 1).

Jednak stale te są wrażliwe na obróbkę cieplną i tego powodu próby łączenia termicznego wpływają na 


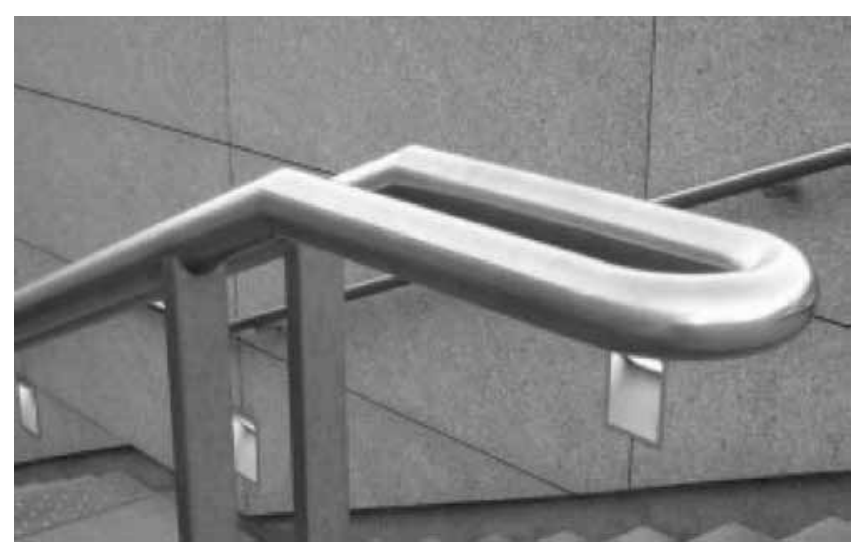

Rys. 1. Poręcz wykonana ze stali nierdzewnej

Fig. 1. The austenitic steel balustrade

właściwości mechaniczne w strefie wpływu ciepła. Już w temperaturze $550 \div 750^{\circ} \mathrm{C}$ wydziela się węglik chromu, co wpływa na przyspieszenie procesu korozji. Kolejnym problemem są tlenki chromu, których temperatura topnienia jest bardzo wysoka $\mathrm{T}_{\text {top }} \mathrm{Cr}_{2} \mathrm{O}_{3}=2437^{\circ} \mathrm{C}$, co $w$ dużym stopniu utrudnia spajanie $[3,4]$.

\section{Proces łączenia}

Budowa lutowanego złącza zależy przede wszystkim od rodzaju wzajemnego oddziaływania na siebie lutowanego metalu podłoża i lutu, a więc od ich składu chemicznego i właściwości. Istotny wpływ wywieraja również takie czynniki, jak temperatura procesu, wielkość szczeliny między łączonymi powierzchniami, sposób ochrony złącza przed utlenianiem (topniki, atmosfera ochronna), metoda lutowania, ale przede wszystkim właściwe oczyszczenie łączonych powierzchni.

Złożony mechanizm powstawania połączeń lutowanych, oparty na wielu różnych zjawiskach fizykochemicznych, pozwala stwierdzić, że ocena lutowności danego materiału wymaga zwykle uwzględnienia:

- sposobu przygotowania i stanu powierzchni lutowanych materiałów (w szczególności materiałów, na których znajdują się trudne do usunięcia warstewki tlenkowe),

- kształtu i wymiarów złącza,

- rodzaju i postaci lutowia,

- rodzaju i postaci topnika lub rodzaju atmosfery kontrolowanej,

- metody, techniki i przebiegu temperaturowo-czasowy nagrzewania i chłodzenia złącza.

Do niedawna lutowanie stali nierdzewnej odbywało się za pomocą lutów cynowo-ołowiowych, jednak ze względu na szkodliwy wpływ ołowiu na organizm ludzki i środowisko wycofano stosowanie tej grupy stopów. Obecnie do lutowania stali nierdzewnych w powietrzu stosuje się luty cynowo-srebrowe, a także specjalne stopy lutownicze na bazie srebra $z$ dodatkiem miedzi, indu, niklu, cynku i cyny o stosunkowo niskich temperaturach topnienia (ok. $600 \div 750^{\circ} \mathrm{C}$ ) oraz topniki fluorkowe o wysokiej aktywności. Wyeliminowano za to lutowia miedziano-fosforowe, które nie nadają się bezpośrednio do lutowania stali $\mathrm{Cr}-\mathrm{Ni} \mathrm{z}$ powodu tworzenia kruchych faz międzymetalicznych na granicy stal - lutowina [5, 6].

W procesie lutowania istotnym czynnikiem jest zwilżalność powierzchni materiału przez stop lutowniczy. Charakter i stopień rozpływności zależy od powinowactwa chemicznego metalu łączonego i lutu, temperatury procesu, aktywności topnika albo atmosfery redukcyjnej lub wysokości podciśnienia (próżni), tekstury powierzchni, stanu jej utlenienia itp. czynników. Dlatego podczas lutowania stali nierdzewnej należy pamiętać o tlenkowej powierzchni ochronnej, która musi zostać usunięta aby połączenie było właściwe. Czystość powierzchni można osiągnąć przez mechaniczne lub chemiczne/elektrochemiczne usunięcie warstwy tlenków z powierzchni materiału. Następnie należy zastosować topniki bądź atmosferę ochronną aby uniemożliwić ponowny wzrost warstwy ochronnej.

\section{Trudności lutowania stali austenitycznych}

Wszystkie stale nierdzewne, przy wyjściu z huty są poddawane specjalnemu procesowi, w którym powierzchnia blachy jest dodatkowo pasywowana, co przyspiesza naturalny wzrost warstwy tlenku chro$\mathrm{mu}$. Proces ten chroni stal nierdzewną w czasie transportu i magazynowania przed korozją. Podczas gdy tworzymy z materiału jakiś element, musimy go pociąć, odkształcić, a następnie połączyć. Te procesy powodują zmiany w strukturze molekularnej blachy w poblizu miejsca łączenia. Jednak wszelkiego rodzaju przebarwienia, naloty tlenków żelaza i inne chemiczne uszkodzenia powierzchni można usunąć za pomocą obróbki ściernej oraz preparatów trawiących. Dodatkowo stale Cr-Ni charakteryzują się dużą rozszerzalnością i małą przewodnością cieplną, co należy również uwzględnić podczas projektowania złączy i oprzyrządowania oraz wyboru metody lutowania i cyklu nagrzewania. Należy też wziąć pod uwagę skłonność nierdzewnych stali austenitycznych do korozji międzykrystalicznej i stosować możliwie krótkie czasy nagrzewania podczas lutowania. Przegrzanie złączy prowadzi do utworzenia bardzo trwałej warstewki tlenkowej $\mathrm{Cr}_{2} \mathrm{O}_{3}$ niezwilżanej przez lut, co uniemożliwia uzyskanie poprawnego połączenia lutowanego [7]. Podczas lutowania stali austenitycznych istnieje także zagrożenie związane z wystąpienia korozji naprężeniowej, która może doprowadzić nawet do zniszczenia złącza lutowanego na granicach ziarn austenitu, spowodowanego głęboką penetracją ciekłego lutu, zwłaszcza na osnowie miedzi. Zapobiegając występowaniu takiego zjawiska, należy: wyżarzyć przed lutowaniem elementy wykonywane metodami przeróbki plastycznej celem usunięcia naprężeń wewnętrznych, nie stosować przyrządów 


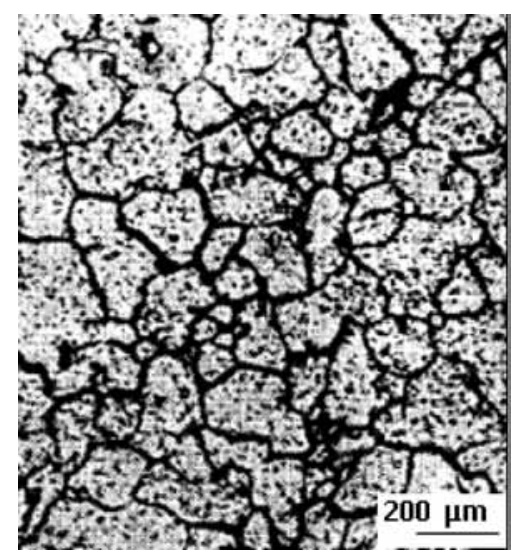

Rys. 2. Korozja międzykrystaliczna austenitycznej stali Cr-Ni 18/8, stan nietrawiony [9]

Fig. 2. Intercrystalline corrosion in $\mathrm{Cr}-\mathrm{Ni}$ austenitic steel - 188 type, without etching [9]

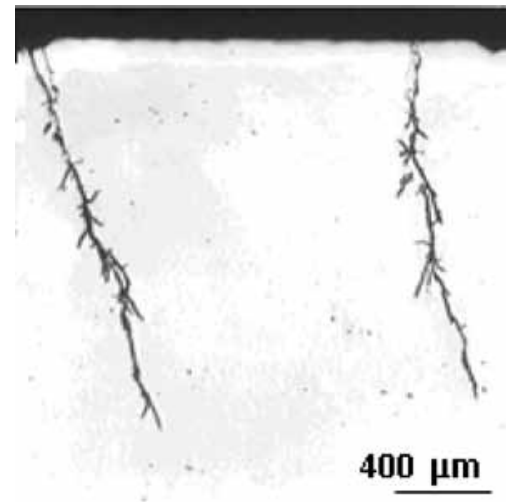

Rys. 3. Korozja naprężeniowa w stali $18 / 10$ przebiegająca po granicach ziarn austenitu, stan nietrawiony [10]

Fig. 3. Stress corrsion in 18-10 steel in austenite grain boundaries, without etching [10]

wywołujących naprężenia elementów w strefie lutowania, stosować sposoby nagrzewania minimalizujące wystąpienie naprężeń cieplnych w złączu [5]. Duży współczynnik rozszerzalności cieplnej stali czy przewodności cieplnej, można przyczynić się do wystąpienia odkształceń i naprężeń szczątkowych oraz kumulacji energii w strefie wpływu ciepła, a także zmiany struktury stali pod wpływem ciepła objawiającej się wydzieleniem węglików chromu na granicach ziarn austenitu. Powoduje to zubożenie przygranicznych stref ziarna w chrom, zmniejszając tym samym odporność stali na działanie korozji międzykrystalicznej. Mogą wystąić wtedy pęknięcia na gorąco, wydzielanie kruchej fazy międzymetalicznej $\sigma$ i występowanie korozji powierzchniowej, naprężeniowej lub międzykrystalicznej (rys. 2, 3) [8].

Stale austenityczne podczas termicznego procesu łączenia wykazuja skłonność do pęknięć na gorąco [8]. Podstawową przyczyna występowania tego zjawiska są niskotopliwe eutektyki $\mathrm{Ni}_{3} \mathrm{~S}_{2}-\mathrm{Ni}$ oraz $\mathrm{Ni}-\mathrm{Nb}$, których temperatury topnienia wynoszą odpowiednio 645 i $1270^{\circ} \mathrm{C}$ [11]. Są one usytuowane zwykle na granicach ziarn i mają duży wpływ na pogorszenie spójności międzykrystalicznej. Istotnym zagrożeniem jest również tworzenie się kruchej fazy międzymetalicznej 6 typu $\mathrm{Fe}-\mathrm{Cr}$, której sprzyja nie tylko nagrzewanie w zakresie temperatury $600 \div 850^{\circ} \mathrm{C}$, ale także obecność naprężeń spowodowanych zgniotem na zimno. Obecność fazy $\sigma$ pogarsza plastyczność materiału, wpływa niekorzystnie na udarność w niskich temperaturach oraz pogarsza właściwości antykorozyjne stali. $Z$ uwagi na reakcję fosforu z żelazem i niklem lutowanie

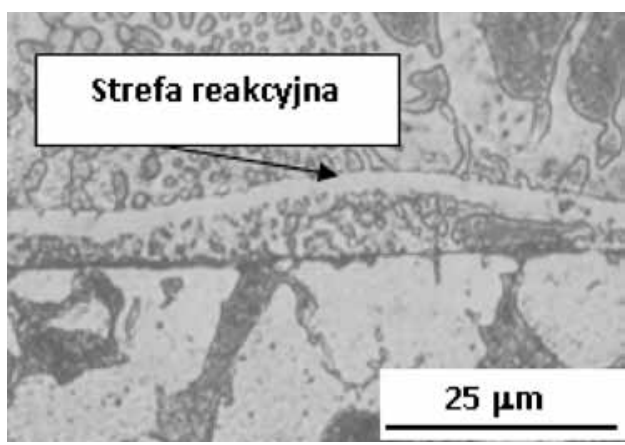

Rys. 4. Strefa reakcyjna $z$ fosforkami żelaza w lutowinie AG 304 $+0,3 \% P[13]$

Fig. 4. Stress relaxation zone with iron phosphide in AG $304+0,3 \%$ $P$ solder [13]

stali chromowo-niklowych spoiwami na osnowie Cu-P jest zabronione, gdyż na granicy stal-lutowina powstają kruche fazy międzymetaliczne $\mathrm{Fe}_{2} \mathrm{P}$ i Ni $\mathrm{Ni}_{2} \mathrm{P}$, które wykazują ograniczoną rozpuszczalność $\mathrm{w}$ miedzi i zwiększają skłonność złączy do pęknięć (rys. 4) [12].

Trwałość połączenia lutowanego zależy bezpośrednio od dobrej jakości połączenia. Należy więc spełniać wymogi dotyczące właściwego przygotowania powierzchni, zastosowania odpowiednich materiałów dodatkowych, a także doboru techniki lutowania w połączeniu ze staranną obróbką wykańczającą lutowiny.

Rozpływność lutu po powierzchni części lutowanych zależy od wielu czynników, w tym przede wszystkim od czystości powierzchni, aktywowanej często topnikami lub gazową atmosferą redukcyjną. Jeżeli topnik nie zwilży powierzchni styku części lub jeśli atmosfera gazowa nie będzie miała dostatecznego dostępu do złącza, to lut nie rozpłynie się po powierzchni części złącza lub może wystąpić tylko częściowe wypełnienie szczeliny lutem, co można zaobserwować na rysunkach $5 \mathrm{c}$ i $5 d$.

\section{Przygotowanie powierzchni}

\section{Metody oczyszczania stali nierdzewnej}

Bez względu na metodę łączenia i rodzaj złącza zasadniczą sprawą jest właściwe oczyszczenie łączonych materiałów zarówno przed ich połączeniem, jak i po połączeniu. Oczyszczenie powierzchni z wszelkich tlenków, olejów, smarów, brudu oraz innych obcych ciał pozwoli uzyskać lutowiny o estetycznym wyglądzie i dobrych właściwościach mechanicznych [14]. Jednak należy pamiętać, że po wytrawieniu na powierzchni metalu natychmiast wytwarza się ochronna warstwa tlenków chromu, jeżeli tylko ma styczność z powietrzem lub wodą. Jest to naturalna pasywacja metalu, która bardzo przeszkadza przy procesach łączenia materiałów. Dlatego po oczyszczeniu powierzchni metodami mechanicznymi, chemicznymi czy elektrochemicznymi stosuje się topniki, które w sposób mechaniczny ograniczają dostęp atmosfery do punktu lutowania, a także 


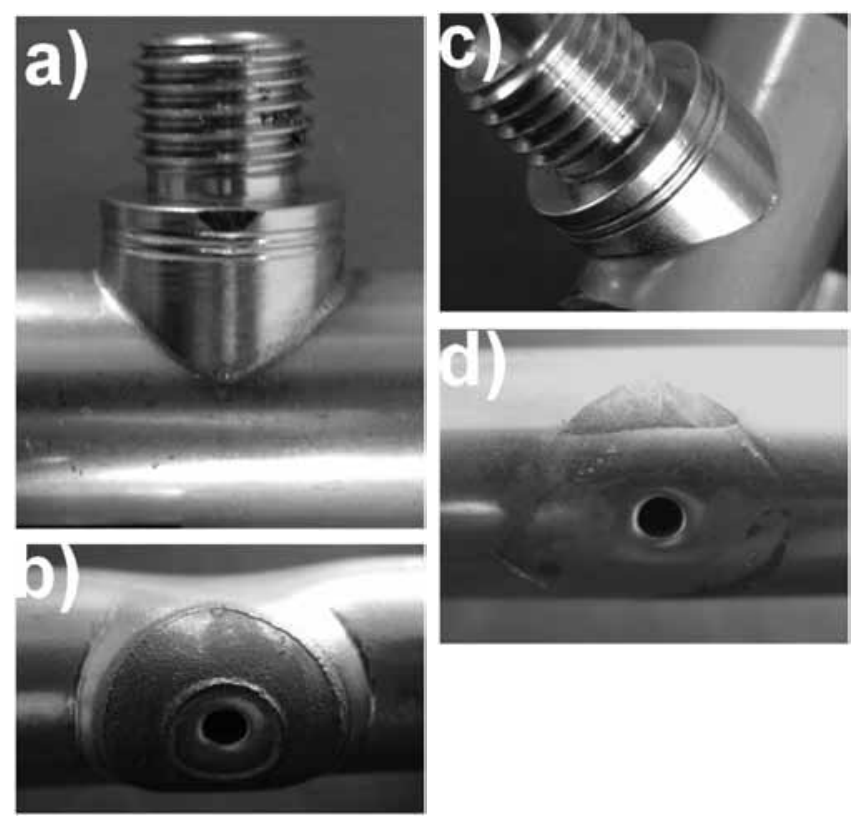

Rys. 5. Przykłady wpływu przygotowania części do lutowania na wypełnienie szczeliny lutowniczej: a) złącze poprawne z prawidłową wypływką lutu, b) lut na całej powierzchni styku części z rys. 5a, c) złącze wadliwe niewypełnione lutem, d) lut lokalnie zwilżył powierzchnie styku części w złączu $z$ rys. $5 \mathrm{c}$

Fig. 5. An example of the impact of the preparation of the solder to fil in the gap solder: a) correct solder joint shape; b) solder on the entire contact surface from Fig. $5 \mathrm{a}$; $\mathrm{c}$ ) the defective joint - not filled gap by solder; d) locally wetted by solder surfaces in the joint from Fig. $5 \mathrm{c}$

przygotowuja powierzchnię, oczyszczając ją chemicznie z produktów utleniania, mogą również wspólnie z lutem wchodzić częściowo w reakcje, które sprzyjają poprawie właściwości tworzonego lutowia. Głównym zadaniem topników jest oczyszczenie i utrzymanie odtlenionej powierzchni w takim stanie, aby zwiększyć rozpływność lutu przez zmniejszenie napięcia powierzchniowego w miejscu styku powierzchni.

Przygotowanie powierzchni ze stali nierdzewnej zawsze zależy od późniejszej eksploatacji w określonym środowisku. Dla bardziej surowych korozyjnie warunków wymagane jest dokładniejsze przygotowanie powierzchni.

\section{Metody oczyszczania mechanicznego}

Oczyszczanie mechaniczne wiąże się z użyciem narzędzi. Wyróżniamy tu m.in. takie techniki jak:

- Szczotkowanie, które umożliwia uzyskanie powierzchni pozbawionych luźnych produktów korozyjnych.

- Szlifowanie za pomocą szlifierek tarczami ściernymi; jest to metoda oczyszczania, wygładzania i zaokrąglania ostrych krawędzi elementów, jak i oczyszczania m.in. złączy nitowanych, spawanych itp.

- Polerowanie polegającymi na usunięciu rys powstałych podczas innych zgrubnych metod oczyszczania. Zapewnia najwyższą gładkość powierzchni. Może być realizowane mechanicznie lub elektrolitycznie. W przypadku polerowania mechanicznego stosuje się obrotowe tarcze polerskie pokryte filcem i zwilżone wodną zawiesiną $\mathrm{Al}_{2} \mathrm{O}_{3}, \mathrm{Fe}_{2} \mathrm{O}_{3}$ lub $\mathrm{Cr}_{2} \mathrm{O}_{3}$, a także pasty diamentowe o bardzo małej ziarnistości. Sam przebieg polerowania musi być przeprowadzony $z$ dużą dokładnością, tak aby nie utworzyć umocnionej warstwy powierzchniowej, tzw. warstwy Bilby'ego, wywołanej zbyt dużym naciskiem obrabianego przedmiotu na tarczę polerską.

- Oczyszczanie strumieniowo-ścierne, które polega na tym, że ziarna materiału ściernego $z$ dużą prędkością w strumieniu gazu lub/i cieczy zostają skierowane na przeznaczoną do oczyszczenia powierzchnie. Po tej obróbce otrzymuje się powierzchnie metalicznie czyste, pozbawione wszelkich zanieczyszczeń stałych, takich jak tlenki, pozostałości lakierów i farb. Jednak nie usuniemy tą metodą olejów, smarów, emulsji, śladów kwasów ani alkalii oraz grafitu, smarów ciągarskich i past polerskich. Dlatego przed zastosowaniem tej metody oczyszczania wstępnie oczyszczamy elementy chemicznie (odtłuszczamy lub zobojętniamy).

- Oczyszczanie luźnym ścierniwem polegające na umieszczeniu drobnych elementów wraz ze ścierniwem w specjalnym urządzeniu, a następnie wprawieniu tego pojemnika w ruch obrotowy lub wibracyjny (obróbka w bębnach obrotowych lub wibracyjnych, gdzie dodatkowo wsad zwilżany jest $z$ reguły roztworem mieszanki chemicznej.

\section{Metody oczyszczania chemicznego i elektrochemicznego}

Obróbka chemiczna detalu może być procesem końcowym lub procesem wstępnym przed polerowaniem elektrochemicznym. Wśród dostępnych metod stosowane są:

- Odttuszczanie w rozpuszczalnikach organicznych.

Najczęściej jest to zabieg wstępny przed innymi metodami. Rozpuszczalniki stosowane do odtłuszczania to m.in. benzyna i nafta.

- Odttuszczanie w roztworach alkalicznych. Polega na zmydlaniu tłuszczów roślinnych i zwierzęcych oraz emulgowaniu olejów mineralnych przez alkalia.

- Odłuszczanie emulsyjne. Zatłuszczoną powierzchnię lub zanieczyszczoną po obróbce mechanicznej, poddaje się działaniu emulsji zawierającej związki powierzchniowo czynne oraz rozpuszczalniki.

- Odtfuszczanie elektrolityczne - zemulgowanie tłuszczów i olejów za pomocą wydzielających się w procesie elektrolizy pęcherzyków gazów: wodoru na katodzie i tlenu na anodzie. Blachy umieszcza się $w$ wannie $z$ roztworem alkalicznym jako katodę lub jako anodę i poddaje działaniu prądu stałego.

- Trawienie - metoda usuwania tlenków z powierzchni metali za pomocą roztworów kwasów, wodorosoli 
lub alkaliów. Może być realizowane chemicznie tzn. bez przepływu prądu elektrycznego, lub elektrolitycznie.

- Trawienie chemiczne. Zanurzenie przedmiotów w odpowiednich roztworach kwasów lub alkaliów - gdzie zachodzi reakcja z tlenkami znajdującymi się na powierzchni danego metalu. W przypadku wyrobów stalowych trawienie chemiczne polega na usuwaniu rdzy oraz zgorzeliny za pomocą kwasów mineralnych.

- Trawienie elektrolityczne. Zachodzi w wyniku działania prądu elektrycznego. Proces może być prowadzony katodowo (redukcja tlenków metalu za pomocą wydzielającego się wodoru) lub anodowo (rozpuszczanie oraz mechaniczne odrywanie tlenków w wyniku wydzielania się tlenu). Podstawowym składnikiem elektrolitu do trawienia elektrolitycznego jest z reguły kwas siarkowy.

\section{Wnioski}

Przed procesem lutowania powierzchnia powinna być pozbawiona wszelkich zanieczyszczeń, bowiem niewłaściwe przygotowanie powierzchni spowoduje wiele ujemnych skutków, takich jak: brak zwilżalności, zmniejszenie przyczepności lutu do podłoża/ przyklejenie i gładkości powierzchni, rozwój korozji podpowłokowej oraz brak właściwej dyfuzji materiału/pierwiastków lutu w głąb stali.

Jako gazy osłonowe zaleca się stosować gazy obojętne, w celu ograniczenia do minimum procesu
- Polerowanie chemiczne - rozpuszczanie powierzchni obrabianych elementów, co powoduje ich stopniowe wygładzenie. W czasie polerowania rozpuszczeniu ulegają jedynie wierzchołki nierówności, a wgłębienia pozostają bez zmian.

- Polerowanie elektrolityczne - anodowe rozpuszczanie powierzchni metalu podłoża w odpowiednio dobranym elektrolicie. Stosowane elektrolity stanowią zwykle mieszaninę związków utleniających oraz kwasów.

\section{Termiczne oczyszczanie powierzchni}

Oczyszczanie płomieniowe - polega na tym, że powierzchnię pokrytą śladami korozji, zgorzeliny, starą powłoką malarską i innymi zanieczyszczeniami poddaje się działaniu płomienia pochodzącego z palnika gazowego.

nawęglania metalu spoiny. Ze względu na możliwość deformowania i odkształcania się łączonych materiałów zaleca się dodatkowe usztywnianie elementów. Do czyszczenia złącza po lutowaniu należy używać szczotek wykonanych z nierdzewnej stali chromowej lub chromowo-niklowej.

Jako gazy osłonowe zaleca się stosować gazy obojętne, w celu ograniczenia do minimum procesu nawęglania metalu spoiny

\section{Literatura}

[1] Wróbel M., Nowak S., Blacharski M.: Inżynieria Materiałowa 3 (2003) 101-110.

[2] Przybyłowicz K.: Metaloznawstwo, WNT, Warszawa 2009.

[3] Mirski Z., Granat K., Bulica A.: Problemy występujące przy spajaniu miedzi ze stalą kwasoodporną, VIII Konferencja Naukowo-Techniczna, Problemy i innowacje w remontach energetycznych PIRE 2005, Wyd. OBR Gospodarki Remontowej Energetyki, Wrocław 2005, s. 211-222.

[4] Mirski Z., Granat K., Winiowski A., Bulica A.: Porównanie metod spajania miedzi ze stalą austenityczną, Inżynieria Materiałowa, $\mathrm{nr}$ 3/2006, s. 205-208.

[5] Pilarczyk J.: Poradnik inżyniera. Spawalnictwo, t. 2 (pod red. J. Pilarczyka), WNT, Warszawa 2005.

[6] Mirski Z., Granat K., Prasałek A.: The diffusive barriers in copper brazing with austenitic steel by use the Cu-Ag-P (L-Ag15P) filler metal, The Archives Metallurgy and Materials, t. $53,4 / 2008$, s. $1035-1046$.
[7] www.euro-inox.org/pdf/map/StainlessSteelProperties_PL.pdf

[8] Tasak E.: Metalurgia spawania, Wyd. JAK, Kraków, 2008.

[9] www.ewamalecka.republika.pl/elements/cu.htm

[10] Dudziński W.: Atlas struktur metali i stopów, Instytut Mechaniki Technicznej i Materiałoznawstwa, Opracowanie wewnętrzne, Politechnika Wrocławska, Wrocław 1995.

[11] Mirski Z., Granat K., Prasałek A.: Lutowanie twarde miedzi ze stalą chromowo-niklową w urządzeniach chłodniczych, Polski Instalator, nr 9/2007, s. 72-76.

[12] Mottram D.R., Wronski A.S., Chiton A.C.: Brazing copper to mild and stainless steels using copper - phosphorus - tin pastel, Welding Journal, April 1986, s. 43-46.

[13] Siebert R., Zimmermann K. F.: Löten als Verbindungstechnik für metallische Werkstoffe, H. 27, Technik die verbindet, Hanau 1975.

[14] Spawanie. Wytyczne dotyczące spawania metali; PKN, PN-EN 1011-3, listopad 2002. 